\title{
Resenha do livro: Perspectivas globais na Educação Superior
}

\author{
Book review: Global perspectives in Higher Education
}

Reseña de libro: Perspectivas globales en la Educación Superior

\author{
REBECCA GAVILLET* \\ JENNIFER ZAMORA**
}

A educação é inerentemente uma questão global. As sociedades incorporam enraizadas expectativas históricas e metas aos objetivos da Educação Superior. À medida que o mundo se torna mais conectado, através de avanços tecnológicos e viagens internacionais facilitadas, às discussões sobre o impacto da globalização se tornam cada vez mais presentes. A globalização, o sistema de interação e integração de pessoas, culturas e ideias de diferentes países, não é algo novo (ERIKSEN, 2007), há milhares de anos existem culturas integradas, através de práticas comerciais, guerras e existência nômade. Em um mundo pós-colonial, o impacto desta integração continua a se expandir e, se as instituições querem se desenvolver nesta realidade, os responsáveis pela administração da Educação Superior devem estar preparados com conhecimento, compreensão do contexto histórico e das tendências emergentes da globalização.

Philip Altbach é professor pesquisador e diretor fundador do Centro de Educação Superior Internacional do Boston College. Até o momento desta publicação, Altbach foi tanto autor como editor de mais de cinquenta livros, e este texto é resultado de cinquenta anos de estudo sobre Educação Superior Internacional através de seus trabalhos em campus ao redor do globo. Em seu livro Global Perspectives on Higher Education, Altbach (2016) se utiliza de uma abordagem analítica para explorar a influência da internacionalização da Educação Superior no século XXI. Ao longo das cinco seções do texto, o pesquisador e seus colaboradores, tanto do Centro de Educação Superior Internacional do Boston College como do Instituto de Estudos em Educação de Ontário, abordam os principais elementos, pressupostos, influências e tendências emergentes da globalização no setor da Educação Superior.

$\mathrm{Na}$ primeira seção o autor descreve "o contexto global" e como o impacto de constantes mudanças na demografia em diversos países ao redor do globo influenciaram na implementação da educação. Essas transformações desdobram-se desde a crescente privatização da Educação Superior, a mudanças nos cursos/diplomas oferecidos, introdução da educação à distância e novo foco nos programas de educação profissional, resultado da massificação. Em nível global, nunca tantos estudantes buscaram a Educação Superior e, como tal, os países são encarregados de definir não apenas se a Educação Superior é um bem público ou privado, mas também de que forma proporcionar esse nível de ensino aos seus cidadãos A Educação Superior se deslocou de instituições que atendiam exclusivamente aos ricos e elites sociais para um processo central de prosperidade de uma sociedade. Nesta seção, Altbach dá especialmente ênfase as "superpotências acadêmicas" emergentes, utilizando como estudo de caso os contextos de Brasil, Rússia, Índia e China e suas singularidades no contexto mundial moderno da Educação, juntamente a isto analisa o contexto histórico e os impactos do

\footnotetext{
*Coordenadora do Programa Sênior na Graduate School of Business, da Universidade do Texas em Austin. E-mail: <rebecca.gavillet@mccombs. utexas.edu>.

**Pesquisadora Senior UX no Google. E-mail: <jenniferlzamora@gmail.com>.
} 
pós-guerra na globalização no capítulo seis, o que auxilia a preparar o cenário para o restante do livro.

$\mathrm{O}$ autor dedica tempo detalhando as experiências individuais nacionais em um mundo cada vez mais integrado. A segunda seção do livro apresenta as "Implicações da Globalização" e a terceira seção aborda os temas "Centros e Periferias". Juntas, ambas aprofundam a análise das desigualdades e impactos da influência ocidental sobre a educação através de temas como, rankings e idiomas, bem como considera de que forma países e instituições estão gerenciando estas perspectivas para encontrar seus rumos. Existem profundas e marcantes divisões entre os que possuem e os que não possuem, e universidades nos países em desenvolvimento estão em desvantagem quando competem no nível global. $\mathrm{Na}$ medida que, tentam olhar simultaneamente para dentro e para fora para enfrentar as carências reais e sentidas de seus sistemas educacionais

Altbach se preocupa em distinguir internacionalização e globalização, definindo a última como "as forças econômicas, políticas e sociais que impulsionam a Educação Superior do século XXI para um maior envolvimento internacional" (p.105). Nesse sentindo, a globalização afeta todos os aspectos da sociedade e seus defensores consideram estes impactos positivos, pois impulsionam as economias através da ampliação do comércio e investimentos. Expandindo o desenvolvimento e melhorando a sociedade como um todo. No entanto, os críticos argumentam que este processo expande as desigualdades estruturais, através da disseminação de ideias imperialistas das culturas ocidentais dominantes. Assim, a globalização tende a ampliar as disparidades econômicas e aprofunda as desigualdades. Quando as ideologias ocidentais, em torno do lucro e do capitalismo, se intersecionam com a globalização dos rankings e o domínio da língua inglesa, os resultados incluem a ausência de foco no ensino, excessiva ênfase na pesquisa e aumento da fuga de cerébros, "brain drain", de países em desenvolvimento. Embora as inovações na Educação Superior tenham permitido que instituições e governos se beneficiem de diversas maneiras, Altbach solicita que consideremos tanto o custo real para os estudantes, quanto o impacto institucional deste processo.

O impacto da globalização nas trocas estudantis e mobilidade é discutido extensivamente no capítulo oito, "Educação Superior atravessa Fronteiras", onde a facilidade e o entusiasmo para estudar no exterior, bem como os acordos transnacionais, ampliaram o acesso à comunidade internacional. A concorrência mercantil, a distribuição desigual de estudantes americanos realizando mobilidade, a falta de uma verdadeira imersão cultural e a mudança das prioridades institucionais estão limitando a experiência de muitos participantes. No mais, o uso das tecnologias para implementar práticas pedagógicas coloca em pauta a necessidade de viagens físicas, pois agora o estudante pode observar o mundo na privacidade de seu próprio quarto. Este texto foi escrito antes da decisão da Grã-Bretanha de sair da União Europeia, bem como antes do governo dos Estados Unidos promulgar políticas de imigração mais rigorosas e proibições de viagem para vários países - assim, seria interessante conhecer a opinião de Altbach sobre como essas duas históricas mudanças políticas irão impactar tanto nas instituições como nos estudiosos em escala global.

A quarta seção fornece "Perspectivas Comparadas" sobre a Educação Superior e se utiliza dos sistemas educacionais da Índia e China para destacar o impacto das políticas governamentais, religião, castas e políticas sobre a liberdade acadêmica. Um olhar aprofundado sobre a história da educação na Ásia, incluindo o impacto do colonialismo e a Revolução Cultural Chinesa, no capítulo treze, fornece o pano de fundo para melhor compreender os motivos de um modelo de educação asiático não emergir. A burocracia, corrupção acadêmica, disparidade nos pagamentos e questões de acesso/equidade permanecem como desafio para a Educação Superior no continente asiático e sem dúvida, em todo o mundo - e, à medida que essas nações procuram um assento na mesa com seus equivalentes ocidentais, como estas questões afetam o crescimento e o estabelecimento de instituições de pesquisa nesses países?

Por fim, as reações e experiências de professores e estudantes, os dois atores fundamentais do sistema, são apresentadas na quinta seção. Do ponto de vista das faculdades, temas como contratos e salários estão em primeiro plano na Educação Superior. O capítulo dezesseis examina instituições de Educação Superior em 28 países, afim de descrever as tendências e realidades da Educação Superior Moderna a partir uma perspectiva global. O capítulo final, "Ativismo Político Estudantil”, investiga o papel de mobilização e ativismo dos estudantes na academia. Os líderes mundiais são convidados a prestar atenção às ações dos estudantes como indicadores de movimentos sociopolíticos que transcenderão o campus físicos.

Altbach fornece um quadro conceitual para a Globalização da Educação Superior, um processo em evolução que as instituições devem analisar afim de suscitar questões críticas sobre o futuro deste nível de ensino. Este texto é valioso para os públicos interessados na interseção da Educação Superior e expansão global. A globalização é descrita em todos os capítulos tanto como um canal para a inovação da Educação Terciária, bem como um instrumento de opressão; como o processo de globalização não parece estar diminuindo, faz-se importante que estudiosos e profissionais compreendam os dois lados da moeda e possam utilizar essa informação de maneira a acentuar o primeiro e mitigar o último. Altbach foca na 
perspectiva de educação como um bem público e adverte que a privatização pode comprometer este fundamento.

A Educação Superior é, de maneira inextricável, condição fundamental do processo moderno, e em mundo que se torna cada vez menor, as instituições são convocadas a pensar em estratégias de internacionalização em resposta à mudança da natureza da disseminação do conhecimento. Tanto proporcionando uma perspectiva histórica da Educação Superior, como oferecendo considerações sobre as futuras implicações da Internacionalização na Educação Terciária, o texto contribui para a literatura proporcionando uma perspectiva global acerca de processo local. A ampla gama de questões abordadas por Altbach oferecem um alimento significativo para os estudiosos e políticos, assim como para que as instituições de Educação Superior continuem progredindo de maneira global.

(Traduzido do inglês por Caroline Baranzeli)

\section{REFERÊNCIAS}

ALTBACH, P. G. Global perspectives on higher education. Baltimore, MD: Johns Hopkins University Press, 2016.

ERIKSEN, T. H. Globalization: The key concepts. Oxford, UK: Berg. 2007.

Recebido em 15-09-2017.

Aprovado em 20-12-2017. 